\title{
ONCLASSIFIED
}

HANFORD ATOMIC PRODUCTS OPERATION - RICHLAND, WASHINGTON

SERIES AND COPY NO.

$B-3$

DATE

$3-20-57$
X RESTRICTED DATA

THIS DOCUMENT EONTHS RESTRICTED DATA AS

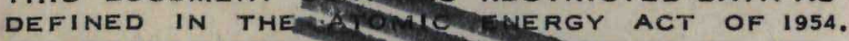
ITS TRANSMITTAL OFMRHEDISELPSURE OF ITS CONTENTS IN ANY MANNER TOS MRENAUTHORIZED PERSON IS PROHIBITED.

OTHER OFFICIAL CLASSIFIED INFORMATION THIS MATERIAL CONTAINS INFORMATION AFFECTING THE NATIONAL DEFENSE OF THE UNITED STATES WITHIN THE MEANING OF THE ESPIONMGE LAWS, TITLE 18, U.S.C., SECS. 793 AND 795, THE MRANSMISSION OR REVELATION OF WHICH IN ANM MANNER TO AN UNAUTHORIZED PERSON IS PROHIBITED BY LAW.

TITLE

GRADED PLATE CARTRTDES FOR PURCX A-TYPS

\section{ExrRacrion coLumes}

AUTHOR

$$
\begin{aligned}
& \text { R. G. Geder } \\
& \text { C. M. Hessos }
\end{aligned}
$$

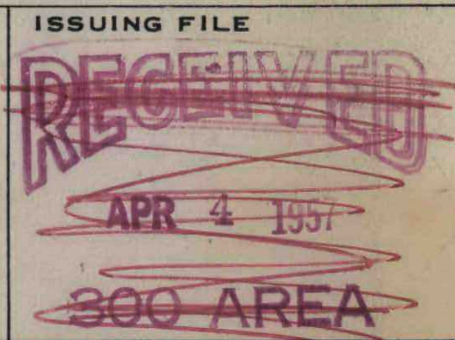

THIS DOCUMENT MUST NOT BE LEFT UNATTENDED OR WHERE AN UNAUTHORIZED PERSON MAYTHAVE ACCESS TO IT. WHEN NOT IN USE, IT MUST BE STORED IN AN APPROVED LOCKED REPOSITORY WITHIN AN APPROVED GUARDED AREA. WHILE IT IS YOUR POSSESSION AND UNTIL YOU HAVE OBTAINEDA SIGNED RECEIPT FROM CLASSIFIED FILES, IT IS YOUR RESPONSIBILITY TO KEEP IT AND ITS CONTENTS WITHIN THE LIMITS OF THIS PROJECT AND FROM ANY UNAUTHORIZED PERSON. ITS TRANSMITTAL TO, AND STORAGE AT YOUR PLACE OF RESIDENCE IS PROHIBITED. IT IS NOT TO BE DUPLICATED. IF ADDITIONAL COPIES ARE REQUIRED, OBTAIN THEM FROM THE RELATED ISSLING FILE. ALL PERSONS READING THIS DOCUMENT ARE REQUESTED TO SIGN IN THE SPACE FROVIDED BELOW.

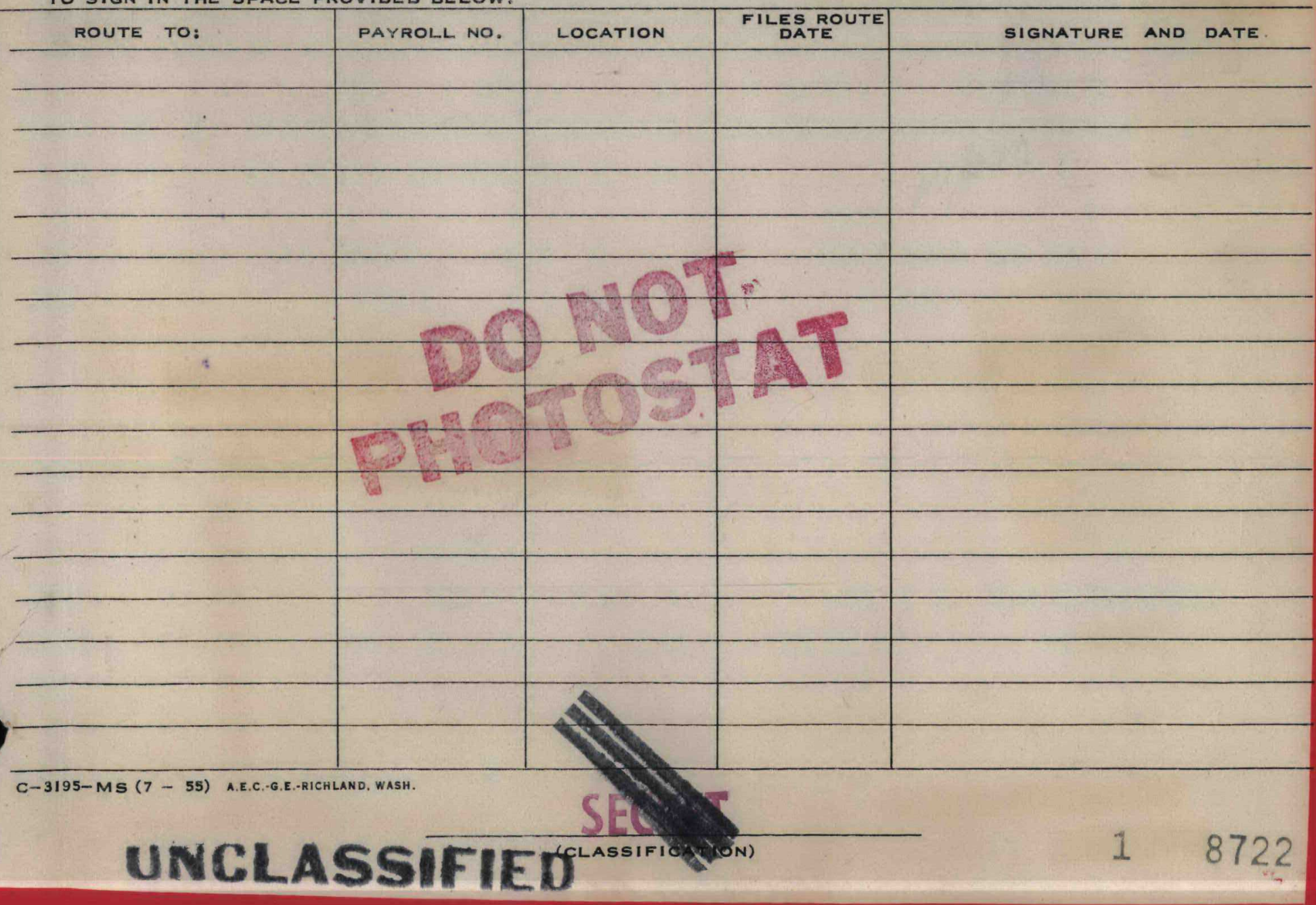




\section{DISCLAIMER}

Portions of this document may be illegible in electronic image products. Images are produced from the best available original document. 


\section{EGAL NOTICE} This report was prepared ao an ony person acting on behalf of the Commission: A. nor anes warranty or representation, expressed or implined, wis report, or that the use A. Mmpleteness, or usefulness of the inforness disclosed in this report may not infringe racy, complietenation, apparatus, method, or process disclosed in tils inform privately owned rights; or

B. Assumes any liabilities wh method, or process disclosed in this report. of any information, appe, "person acting on behalf of the commintractor, to the extent that As used in thactor of the Commission, or employee of such of such contractor prepares, loyee or conee or contractor of the Coming disseminates, or provides access $t$, ant with such contractor.

\section{GRADWD PLATE CARTRTDCES}

\section{FOR PUREX A-TYPE EXIRACTION COLUMN}

This dneawent = iste

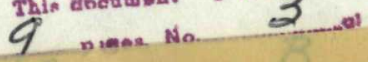

\author{
By \\ R. G. Geier \\ and \\ G. M. Hesson \\ Chemical Bngineering Development \\ Chemical Research and Development \\ HANFORD ILABORATORTISS
}

Photostat Charge $\$ 1.53$

Access Permittees

Available from

Technical Information Service Extension

P. O. Box 1001, Oak Ridge, Tennessee

March 20, 1957

\section{HANFORD ATOMTC PRODUCTS OPERATION RICHIAND, WASHINGTON}

\section{LEGAL NOTICE}

This report was prepared as an account of Government sponsored work. Neither the United States, nor the Commission, nor any person acting on behalf of the Commission:

A. Makes any warranty or representation, express or implied, with respect to the accuracy, completeness, or usefulness of the information contained in this report, or that the use of any information, apparatus, method, or process disclosed in this report may not infringe privately owned rights; or

B. Assumes any liabilities with respect to the use of, or for damages resulting from the use of any information, apparatus, method, or process disclosed in this report.

As used in the above, "person acting on behalf of the Commission" includes any employee or contractor of the Commission to the extent that such employee or contractor prepares, handles or distributes, or provides access to, any information pursuant to his employment or contract with the Commission. 
increased the complete flooding frequency by 10 and 25 cycles per minute at volume velocities of 530 and $1060 \mathrm{gal} . / \mathrm{hr}$. - sq.ft. (sum of both phases), respectively, and exhioited satisfactory extraction efficiency over a wide range of frequencies and throughputs.

\section{DISCUSSION}

The Purex Plant HA, IA, and $2 D$ Columns are identicgl in purpose and have been designated A-type columns. They are dusl-purpose pulse columns, and as designed the diameter ratio of scrub to extraction section was 4 to 3 . Both sections were to contain standard cartridges, i.e., stainless steel sieve plates with $1 / 8$-inchdiameter holes, 23 percent free area, spaced 2 inches apart. The extraction sections were specified to contain four 13 percent free area louver-type redistributor plates, and the scrub sections were'to have three 18 percent free area louver plates.

As shown in Figure 1 , the two sections have radically different flooding characteristics. The two curves for the extraction section indicate cyclic local flooding and complete flooding. While the column is operable at conditions lying between these two curves, such operction is not desirable. The local cyclic flooding curve is generally considered as representing the upper limit of operating conditions.

Insufficient data are avallanie to permit establishing the scrub section flooding curve with the same degree of confidence as the extraction colum curve. However, the curve drawn in Figure 1 represents the most probabie flooding condition.

At volume velocities below $1590 \mathrm{gal} . / \mathrm{hr}$. - sq.ft., the extraction section controls the llooding conditions. In the range of 530 to $1325 \mathrm{gal} . / \mathrm{hr}$. - sq.ft., the maximuia operable pulse frequency as limited by the extraction section varies approximately from 50 to 80 percent of the scruo section flooding frequency. This range is below the 80 to 90 percent of the flooding frequency generally recognized as optimum for pulse column operation.

Recent Purex studies at the Hot Semiworks bave shown that satisfactory plutonium and uranium waste losses are readily attained in the A-type column, but decontamination of the product stream of ission products varied to as much as tenfold below process specifications requirements. While indications are that this problem may be pirtially or even primarily chemical in nature, operation of the A-type scruo sections at pulse frequencies nearer their optimum frequencies would be expected to improve decontanination. Therefore, a development program was started to ontain an A-type extraction certridge whose flooding characteristics would more neerly match those of the scrub section.

The dispersion in ar. A-type extraction colum varies sharply throughout the height of the colum. Nea the top of the colum there is a loose dispersion large drops; lower, there is a tight dispersion of small drops; and below 
this, there is a loose diapersion of larger drops. The reason for this is believed to be related to the mass transfer; that is, a large rate of mass transfer tends to stabilize the formation of large drops. The large uranium transfer near the top of the colum, the relatively large nitric acid transfer in the lower half of the colum, and the low net transfer of either component In the intermediate regions would by this theory account for the disparity in dispersion throughout the column.

Flooding in the extraction section usually originates in the region of tight dispersion. A way of increasing the flooding frequency would be to "open" the cartridge in the region of the tight dispersion, 1.e., increase the sieve plate nole size, free area and/or spacing. Such a cartridge has been designated. as a graded cartridge.

\section{FXXPERIMANTAL, RESULISS}

Seven graded cartridges were investigated in a 3-inch-diameter glass pulsed column and three in a 23.5-inch-dlameter column. The degrees of grading ranged from a plate-free section to various combinations of plate spacing and the inclusion of 33 percent free area sieve plates. The ten graded cartridges are described in detail in Table I. The experimental flooding frequency data are presented in Table II and the experimental H.T.U. data are presented in Table IIT.

Three-Inch-Colum Results. All seven of the graded cartridges for the 3-inchdiameter column increased the conplete floodtng frequencles by 30 to 40 cycles per minute at $1009 \mathrm{gal} . / \mathrm{hr}$. - sq.ft. and 5 to 20 cycles per minute at $530 \mathrm{gal}$. $/ \mathrm{hr}$. sq.ft. The cyclic local flooding frequency was increased proportionally except in Cartridges $F$ and $G$ where it was eliminated entirely.

Observations of the uranium color line positions indicated that satisfactory waste losses could probably be obtained with each of the cartridges at pulse frequencies near the cyclic local flooding frequency. Cartridges $F$ and $G$ exhibited color line positions consistent with low waste losses over a range of frequencies from 60 to 100 cycles per minute.

Extration efficiency mans confirmed the estimates based on uranium color line positions. Cartridges $F$ and $G$ had waste losses lower than 0.001 percent and H.T.U. values less than one foot over a range of throughputs from 265 to $1060 \mathrm{gal} . / \mathrm{hr}$. - sq.ft. and puise frequencies of 60 to 100 cycles per minute.

Large Scale Colum Results. Three graded cartridges were investigated in a 23.5-inch-dianeter extraction section. The first of these, Cartridge H, was "opened" by increasing the plate spacing to 4 and inches in the center of the colum. At a volume velocity of $530 \mathrm{gal} . / \mathrm{hr}$. - sq.ft., this cartridge had

cyclic local floodine frequercy of 10 ; cycles per minute and a complete flooding frequency in excess of 110 cyoles per ninute, the maximum. frequency of the pulse generator. 
Cartridge I was scaled up from Cartridge F, the most promisirig cartridge tested in the 3-inch-diameter column. It exhibited no cyclic flooding, but showed no increase in complete flooding frequency at a volume velocity of $530 \mathrm{gal} . / \mathrm{hr}$. sq.ft. The lack of increase was attributed to the lower two 13 percent free area louver plates in the cartridge. These were replaced with 23 percent free area louver plates to make Cartridge J. This cartridge showed flooding frequency characteristics similar to 3-inch-diameter Cartridge F, which had been scaled up; 1.e., no cyclic local flooding and a complete flooding frequency of 105 cycles per minute at $530 \mathrm{gal} . / \mathrm{hr}$. - sq.ft. and a flooding frequency above the scrub section flooding frequency of 80 cycles per minute at $1000 \mathrm{gal} . / \mathrm{hr}$. - sq. ft.

Efficlency runs made in the 23.5-inch-diameter colum. Indicated that all three cartridges tested gave good extraction efficiency. Cartridge J, the cartridge having the most promising flooding frequency characteristics, had high extraction efficiences at volume velocities from 265 to $1060 \mathrm{gal} . / \mathrm{hr}$. - sq.ft. and frequencies of from 40 to 100 cycles per minute. Typical uranium waste losses were less than 0.001 percent and H.T.U. values were approximately one foot.

of the cartridges studied, $F, G$, and $J$ permitted the ereatest increase in stable operating region and exhibited satisfactory waste losses over a wide range of operating conditions.

The flooding curves for Cartridges $F$ and $J$, together with the scrub section flooding curve, are presented in Figure 2. The match between the scrub and extraction section flooding frequencies has been improved. The maximum stable operating frequency has been increased from 50 to 75 percent of scrub section flooding frequency at $530 \mathrm{grl} . / \mathrm{hr}$. - sq.ft. and from 65 to 100 percent of the scrub section flooding frequency at $1060 \mathrm{gal} . / \mathrm{hr}$. - sq.ft. 
TABTS I

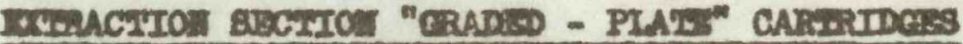

(Cartridges are described Iron top to bottca)

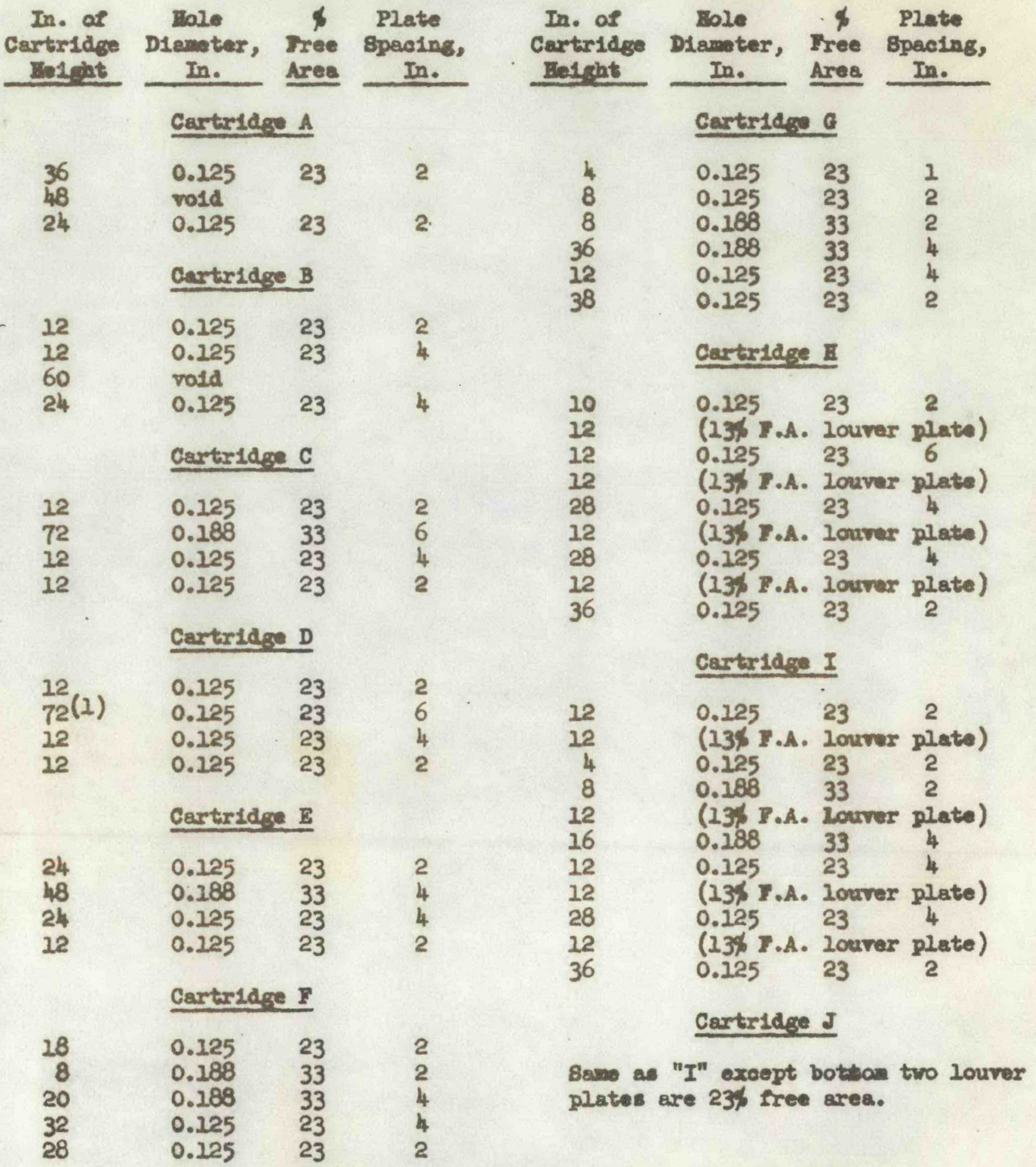

(1) Dossile plates. 0.03-in. noskile depth. 


\section{HA EXIRACTION COLUMN FLOODTMG STUDIES USING GRADED PLATE CARTRIDGES}

Flowsheet: Purex HW \#3, Pu and F.P.'s omitted. Modifled as indicated in remarks.

Bquipment: As noted.

Continuous Phase: Aqueous

\begin{tabular}{|c|c|c|c|c|c|c|}
\hline \multirow[b]{2}{*}{ Run No. } & \multirow[b]{2}{*}{ Equipment } & \multirow{2}{*}{$\begin{array}{l}\text { Cartrigge } \\
\text { Design(a) } \\
\end{array}$} & \multirow[b]{2}{*}{ Diluent } & \multirow{2}{*}{$\begin{array}{c}\text { Gal./(Hir.) (Sq.Ft.), } \\
\text { Sum of Phases }\end{array}$} & \multicolumn{2}{|c|}{ Thresholds } \\
\hline & & & & & Cyclic Iocal & Complete \\
\hline 3-169-AB & (b) & A & Soltrol-170 & 1100 & $95 \pm 5$ & $105 \pm 5$ \\
\hline 3-170-AB & (b) & A & Soltrol-170 & 530 & $105 \pm 5$ & $115 \pm 5$ \\
\hline 3-173a-AH & (b) & B & Soltrol-170 & 530 & -120 & $>120$ \\
\hline 3-175-AB & (b) & C & Soltrol-170 & 530 & $>120$ & $>120$ \\
\hline 3-176-Aㅛㅛ & (b) & C & Soltrol-170 & 1000 & $105 \pm 5$ & $115 \pm 5$ \\
\hline $3-180-A$ H & (b) & D & Soltrol-170 & 530 & None & $115 \pm 5$ \\
\hline 3-181-AH & (b) & D & Soltrol-170 & 800 & None & $115 \pm 5$ \\
\hline $3-182 a-A \mathbb{I}$ & (b) & D & Soltrol-170 & 1100 & $90 \pm 10$ & $>100$ \\
\hline 3-183-AH & (b) & $\mathbf{E}$ & Soltrol-170 & 1100 & $95 \pm 5$ & $105 \pm 5$ \\
\hline 3-184-AH & (b) & $\mathrm{E}$ & Soltrol-170 & 530 & $105 \pm 5$ & $115 \pm 5$ \\
\hline 3-188-AH & (b) & $F$ & Soltrol-170 & 1060 & None & $105 \pm 5$ \\
\hline 3-189-AH & (b) & $F$ & Soltrol-170 & 530 & None & $115 \pm 5$ \\
\hline 3-198-AH & (b) & G & Soltrol-170 & 1000 & None & $105 \pm 5$ \\
\hline $3-200-A H$ & (b) & G & Soltrol-170 & 530 & None & $115 \pm 5$ \\
\hline $\mathrm{PX}-1$ & (c) & H & Shell E-2342 & 530 & $106 \pm 3$ & $>109$ \\
\hline PBM- $4 \mathrm{~b}$ & (c) & H & She.11 E-2342 & 530 & $>90$ & \\
\hline PX-2 & (c) & I & Shell E-2342 & 530 & None & $95 \pm 5$ \\
\hline$P X-4$ & (c) & I & Shell E-2342 & 1060 & None & $>90$ \\
\hline PX-7 & (c) & $\mathrm{J}$ & She11 E-2342 & 530 & None & $105 \pm$ \\
\hline$P X-10$ & (c) & $\mathbf{J}$ & Shell E-2342 & 1060 & None & \\
\hline
\end{tabular}

Notes:

(a) See Table I for a detalled description of the cartridges.

(b) 3.00-inch precision bore glass colum, 9-ft. high. Pulse emplitude of 1.0 inch.

(c) Dual-purpose column. 23.5-in.-dlameter extraction section with 13.5-1t. cartridge, 32-in.-diameter scrub section with 11 to $12 \mathrm{ft}$. of standard cartridge. Pulse amplitude of 1.1 in. in the extraction section

(d) Scrub section flooded at $85 \pm 5$ cycles per minute. 
HA EXTRACTION COLUMN EFTFICIENCY STUDTES USING GRADED PLATE CARTRTUGES

Flowsheet: Purex HW \#3. Pu and F.P.'s omitted. Modified as indicated in remarks.

Equipment: As noted.

Continuous Phase: Aqueous

Cartrigge

Run No. Equipment Design (a)

$3-173 b-A$ H

3-182b-AH

$3-185-\mathrm{AH}$

$3-186-\mathrm{AH}$

3-187-AB

$3-190-\mathrm{AH}$

3-19I-AL

$3-192-\mathrm{AH}$

3-193-AH

3-201a-AH

(b)

(b)

(b)

(b)

(b)

(b)

(b)

(b)

(c)

3-202a $\mathrm{AH}$

$3-206 a-A . M$

$3-2060-A H$

3-207a-AH

3-2070-AH

3-208a-AH

$3-208 b-A H$

PBM-4a

PBM 4 -

PBM-?

$\mathrm{PX}-1$

$\mathrm{PX}-$ ?

PX -8

PX-9

FX-1I

$\mathrm{PX}-12$

$\mathrm{PX}-13$

PX -14

$P X-15$

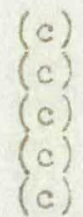 \\ (c) \\ (c) \\ (c) \\ (c)}

(a)

(d)

(d)

(a)

(d)

(a)

(d)

(d)

(d)

(d)

(d)

(d)
Diluent

Soltrol-170

Soltrol-170

Soltrol-170

Soltrol-170

Soltrol-170

Soltrol-170

Soltrol-170

Soltrol-170

Soltrol-170

Soltrol-170

She11 E-2342

Shel1 E-2342

Shell. $8-2342$

She L. I5-2342

She 1] E-2342

She1. E-234

Shell E-2342

She 12. E-234c

She.2] B-234c

She1? E-234

Shelin $8-234$

Sheil B- 34

She1.1 E-234?

Shell E-23+2

She.1. E- 2342

Shell E-2342

She 13 E-33ite

She 1. E-2342

She II $5-234$
Volume Velocity, Gez. (H.) (Sq.Ft.), Frequeney, of $U$ H.T.U., Sum of Dhe

0.030

0.046

0.032

0.0049

0.0021

Ft.
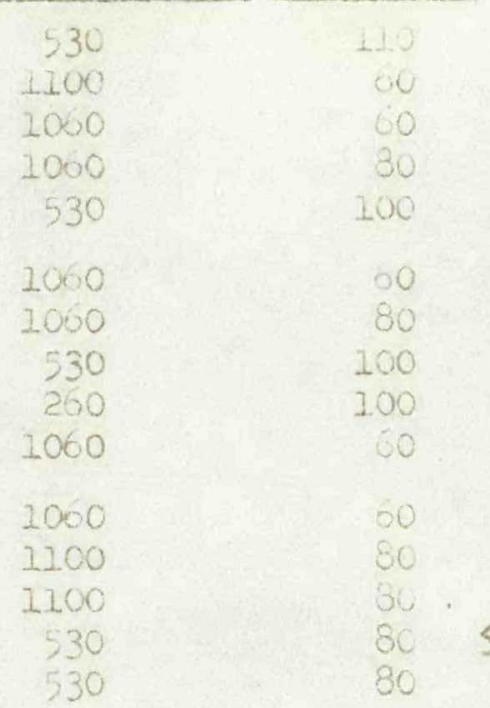

1.08

1.14

1.08

0.86

0.78

1060

00
80
100
100
60

0.0095

0.94

0.0084

0.77

0.0034

0.74

0.0036

0.0079

0.79

$0.93(e)$

1000

0.0094

$0.95(e)$

0.0001

0.03

$80 \cdot \leq 0.0005 \leq 0.72$

$80 \quad 0.0003$

0.70

1060

1060

70
70

0.0011

0.70

0.0011

0.70

530

530

1000

$70 \quad 0.0002$

$1.03(f)$

90

0.0001

$1.00(f)$

000.0000

1.03

530

530

90

0.0002

1.00

60

0.000 ?

.30

1060

1000

260

800

530

90
60
70
50
100

80

40
2.05

0.0003

0.0008

1.13

0.0001

0.0076

0.99

1.40

$\leq 0.00008 \leq 0.96$

$\leq 0.00005$

0.0 .24

0.92

1.51

Notes:

(a) See Table I for a detailed description of the csitridges.

(j) $3.00-i n$. precistion bore glass colum; $9-f^{2}$. higu. Flase amplitude of $2.0 \mathrm{in}$.

(c) Duai-purpose colum. 9-it. lenght of $3.00 \mathrm{~m}$. precision bare glass colum as extraction section. 4nin. suantard bore serub section contaiting $8 \mathrm{ft}$. of standard cartridge. Pulse amplitude of ... in. in the extraction section.

(d) Dual-purpose coluran. 23.5-in.-dismetex extraction section with 13.5 ft. of curtridge. $32-1 n$. - digmeter scrub section with 11 to 12 ft. of standard cartridge. Puise amplitude of 1.i. in. in the extraction section.

(e) Feed was spiked with coating removal waste, 25 pur S1, and 0.003 G. solids/h.

(f) Feed concentration was $1.35 \mathrm{M}, . . \mathrm{M}$ tho 3 , and $1.0 \mathrm{M} \mathrm{NaNO}$. 
